\title{
Climate Prosperity: A Greenprint For Southwest Florida
}

Dr. Joseph Heinzman, Colorado Technical University, Colorado Springs \& Pueblo, USA

Ken Sneeden, Ken Sneeden \& Associates, LLC, USA

Katie Rhodes, MBA Student of Hodges University, USA

John Avola, MBA Student of Hodges University, USA

Frank Blake, MBA student of Hodges University, USA

Tammy Fiedler, MBA student of Hodges University, USA

Volodymyr Zakhvatayev, MBA student of Hodges University, USA

\begin{abstract}
Southwest Florida has been chosen as one of the 8 pilot regions for the Climate Prosperity project. One of the main goals in Southwest Florida is to create and attract jobs to help energize the Southwest Florida economy now as well as future generations. Climate change has edged its way to the top of federal, state, and local agendas. Scientists and leaders across the nation are taking numerous steps to prepare for the positive and negative consequences of a new weather era so that ecosystems, human life, and infrastructure can adapt and survive.
\end{abstract}

\section{ABOUT THE SOUTHWEST FLORIDA GREENPRINT PROJECT}

lobal Urban Development created the Climate Prosperity Project in 2007, with financial support from the Rockefeller Brothers Fund and the Environmental Defense Fund. The Climate Prosperity Project is based on the proposition that responding to the challenges of climate change represents a very substantial economic opportunity (Sustainable Systems, 2009).

Southwest Florida understands that climate and environmental amenities, most particularly the Everglades and the Gulf Coast. The Everglades have always been central to economic prosperity in the region. At the same time the possibility for hurricanes and the fact that much of the region is low lying puts it at risk in relation to sea level rise. Building on the green assets of the state/region, the Southwest Florida Climate Prosperity Strategy is organized as three initiatives -Green Savings, Green Opportunities, and Green Talent (Sustainable Systems, 2009).

Additionally, on February 26, 2009 Southwest Florida Regional Planning Council (SWFRPC) announced that ten area government, business, and industry leaders represented the Southwest Florida region at the National Climate Prosperity Project Leadership Meeting held in San Jose, California (Silicon Valley), on February 20-21, 2009. Southwest Florida is one of eight pilot regions selected to work with Climate Prosperity Project (CCP) to help generate sustainable urban development (Harp, 2009).

Climate Prosperity Project is an economic development partnership that works to encourage energy independence, reduce the impacts of climate change, and protect the environment. CCP encourages the view that protecting the environment need not come at the expense of economic growth. "Climate Prosperity" disputes that climate change is an opportunity to build innovative industry, create new jobs, and grow the economy while addressing one of our most pressing problems, climate change. Participants in this summit meeting exchanged information and ideas on strategies, policies, and projects that can stimulate long term sustainable economic development in our communities. Fort Myers Mayor Jim Humphrey and Sanibel Mayor Mick Denham led the local delegation serving as Chair and Vice Chair of the Southwest Florida Regional Planning Council, respectively (Harp, 2009). 
The group included Ken Heatherington, SWFRPC Executive Director; David Hutchinson, SWFRPC Planning Director; James Paulmann, FAICP, Senior Vice President and Principal of Wilson Miller, Inc. and member of Florida's Century Commission for a Sustainable Florida; Thomas Danahy, President, Babcock Ranch/Kitson \& Partners Communities; Henry Rodriguez, President, SDC Communities and Board member of Enterprise Florida; Ray Rodriguez, Vice President, SDC Communities; and Tony Milner and Dell Jones of Regenesis Power. Southwest Florida's delegation is a group of government and business leaders who continuously demonstrate a strong commitment to sustainable urban growth. Their dedication ranges from developing new communities as models for the future, building alternative energy power plants, and advancing green planning and design principles to serving as expert advisors on regional and statewide commissions and advocating land development policies that will facilitate implementation (Harp, 2009).

\section{STAKEHOLDERS}

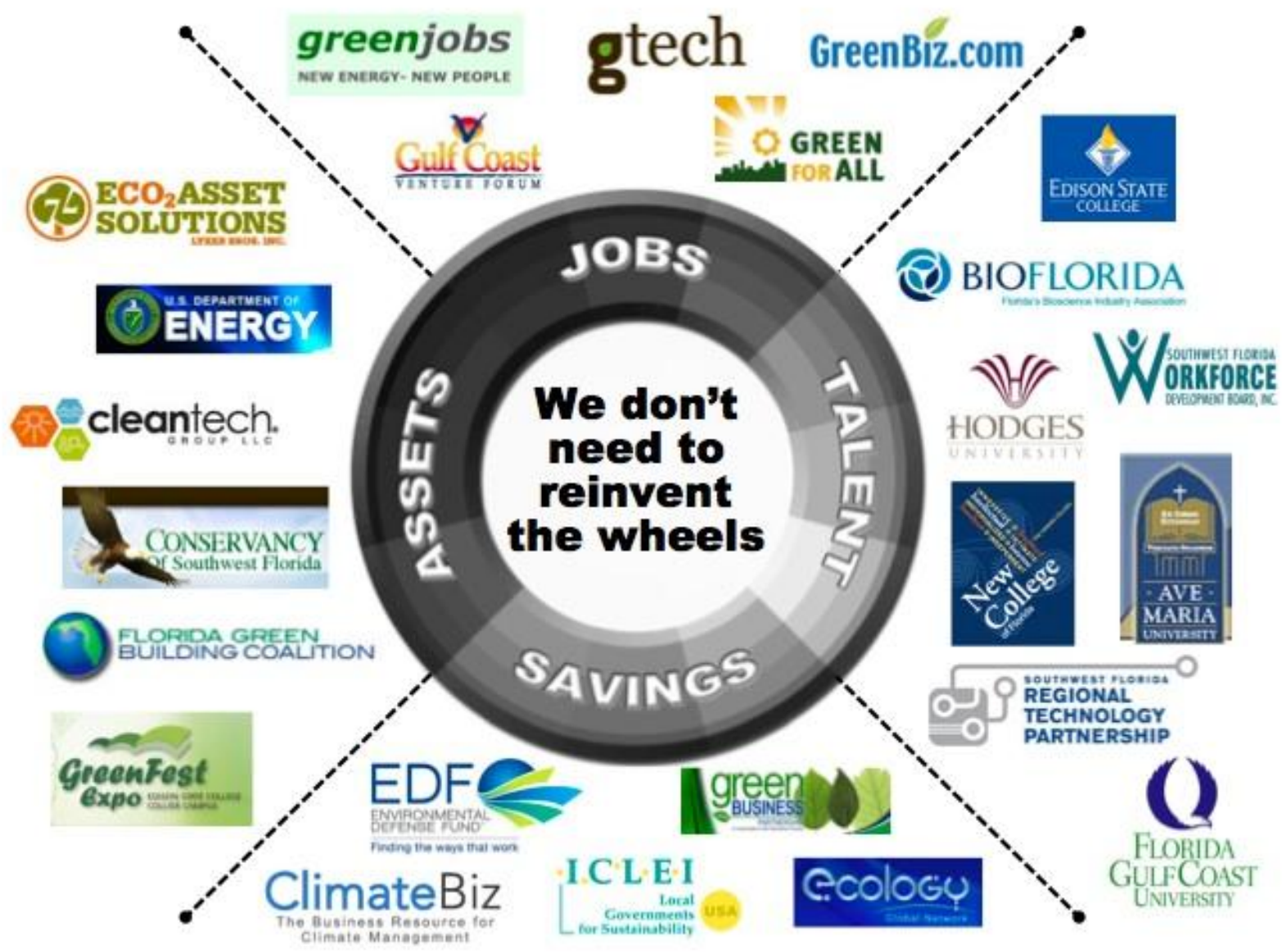

K. Sneeden, Personal Communication, May 17, 2010

\section{EXECUTIVE SUMMARY}

What if we could turn the climate change crisis into an opportunity to build a better world? That is the promise of Climate Prosperity - creating a better, more sustainable world for our children and grandchildren - and what this Greenprint for Southwest Florida is all about. 
We know the climate is changing. We know we need to reduce our use of fossil fuels and prepare for the consequences of a less predictable world. The current administration in Washington is likely to make climate change a priority, but it is up to us to take advantage of the new programs. It is up to us to turn the crisis into an opportunity to create new jobs, invent new products, save money, improve public health, and make Southwest Florida a highly attractive region to pursue these objectives. Together, we can show the nation the way out of the current recession and establish America's global leadership position.

Climate Prosperity says we can have it all: growth in the economy, a thriving business environment, and a solution to the climate crisis. We can innovate, create jobs, train workers for new careers and we can reduce greenhouse gas (GHG) emissions, reduce air pollution, introduce meaningful transportation improvements, and save money.

Southwest Florida is one of seven regions in the country that have agreed to develop Climate Prosperity strategies and prove the concept. Our region is uniquely qualified to show that Climate Prosperity works. We are blessed with talented, energetic leaders and a long list of assets, including:

- $\quad$ A thriving, diverse, clean development cluster supported by entrepreneurs and venture capitalists who see very large, global markets for new eco-friendly developments, such as Babcock Ranch, Ave Maria, Big Cypress, Lakewood Ranch and the Green Mile

- $\quad$ The Southwest Florida Branch of the Green Building Council

- $\quad$ Research programs at Florida Gulf Coast University and Edison State College

- Utilities that are leading the way in reducing the use of fossil fuels for electricity generation and developing a "smart grid" to revolutionize how and where electricity is produced and delivered

- Local government agencies that are developing innovative policies to promote economic growth, reducing their energy consumption, tightening building codes for sustainability, and adjusting general plans to encourage public transit

- Numerous nonprofits and volunteers that are championing the cause of environmental protection, recycling, energy and water conservation, and more

- $\quad$ Community colleges and Universities, labor unions, and workforce development programs that are already helping people prepare for a full range of clean and green jobs, from solar panel and smart meter installers to scientists and engineers

- $\quad$ Florida House, an Institute for Sustainable Development in Sarasota is a non-profit organization that works to "build civic capacity around a practice of vision-centered, place-based planning for a sustainable future." The Institute initiated the Florida House Learning Center as a demonstration home and yard featuring environmentally-friendly building, rainwater harvesting, and sustainable landscaping materials and methods

- Five different county and city sustainability initiatives, including Eco-Smart development, Hurricane/Energy Efficient Retrofits, Green Business Partnership, Climate adaptation, and Environmental Mitigation Banking

In Southwest Florida we have a unique advantage. We both produce and consume many of the technologies, products, and services needed to achieve Climate Prosperity. Our strategy is to stimulate local demand for clean and green technology and supply those solutions to global markets. We are singularly prepared to help the world address the greatest challenge to face civilization.

\section{GREENPRINT FOR SOUTHWEST FLORIDA: ACTION INITIATIVES AND PUBLIC SUPPORT}

To take maximum advantage of these assets on a regional scale, we should bring together leaders from business, government, academia, labor, and the community to develop the strategy we call the Greenprint for Southwest Florida. The strategy provides an overarching framework to coordinate and accelerate the many disparate activities already taking place throughout the entire region. 


\section{The program has two major elements:}

\section{Grow the base of clean and green industries}

The team identified six areas of opportunity to grow local businesses that are developing products and services that reduce dependence on fossil fuels and emissions of greenhouse gases.

- $\quad$ Ensure access to financing that supports business expansion and the purchase of green products

- Help businesses find the land and buildings they need to incubate, launch, and grow

- $\quad$ Promote Southwest Florida's products for export and to attract a talented workforce

- $\quad$ Attract funding for research and development, testing, and commercialization.

- $\quad$ Align workforce training programs with the needs of industry, utilities, and public agencies

- Ensure that the regulatory environment supports innovation and production, and encourages green practices

\section{Build a regional market for clean and green products and services}

There are many opportunities to improve energy efficiency, reduce greenhouse gas emissions, and protect the environment. To begin, the team chose three areas of focus based on the priorities in the Executive Orders signed by Governor Charlie Crist in 2007 aimed at addressing global climate change, reducing greenhouse gases, and increasing the state's energy efficiency.

- $\quad$ Leadership by Example: Immediate Actions to Reduce Greenhouse Gas Emissions from Florida State Government.

- $\quad$ Immediate Actions to Reduce Greenhouse Gas Emissions within Florida.

- $\quad$ Florida Governor's Action Team on Energy and Climate Change.

The State's initiative provides a framework for addressing climate change in Florida, including commitments to reduce emissions and to pursue renewable energy sources such as solar and wind energy, as well as alternative energy such as ethanol and hydrogen.

To preside over the effort, we suggest the development of a council to be called the Southwest Florida Climate Prosperity Council to lead the Climate Prosperity Initiative. The members of the Council will represent business, government, academia, labor, and community organizations, and the Council will have four major roles:

- $\quad$ Coordinating and maximizing the impact of our current activities

- $\quad$ Generating new ideas

- $\quad$ Launching new initiatives, and linking them to supportive public policies, research programs, incubators, workforce programs, and other resources

- $\quad$ Reporting outcomes and tracking progress, using quantifiable measures such as the reduction in GHGs, energy savings, jobs created, and economic growth 


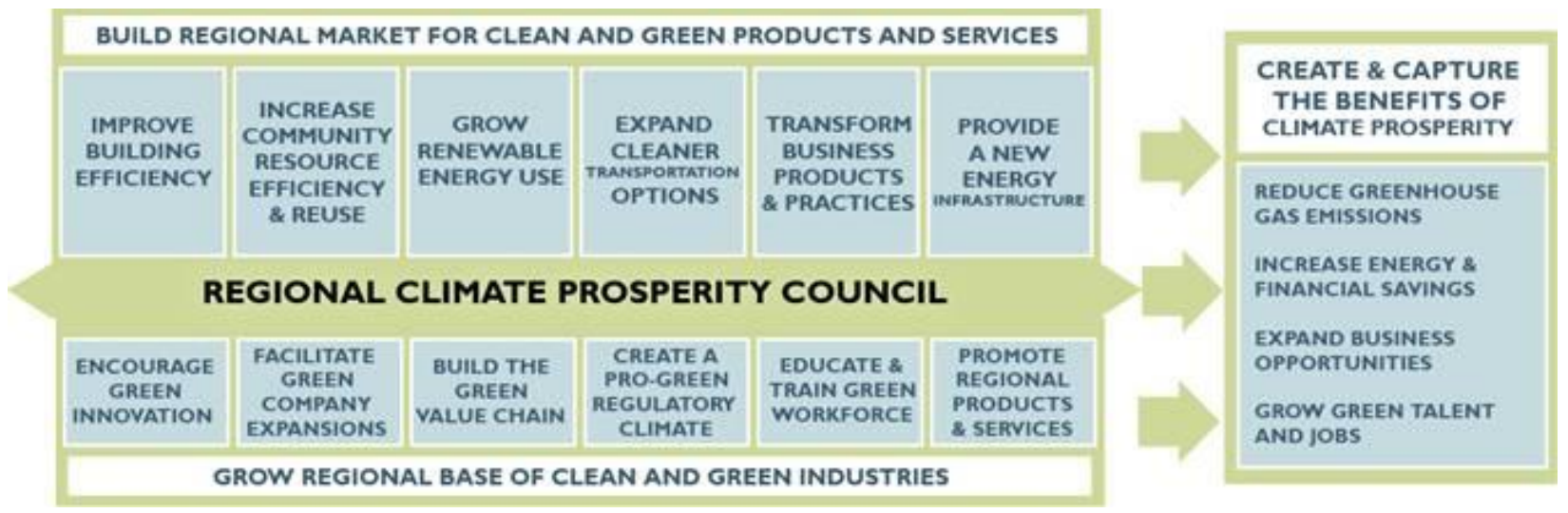

\section{Green Savings, Green Opportunities, Green Talent}

Achieving Climate Prosperity will take hard work and time, but the benefits are powerful:

- $\quad$ More energy efficient homes and cars means less money spent on energy and more disposable income that are likely to stay in the community.

- $\quad$ Adding solar and other renewable energy sources on local homes and offices accomplishes important energy goals, expands a newly emerging sector, and stimulates the local economy.

- $\quad$ Retrofitting homes and offices to be more energy efficient creates new jobs for construction workers, energy auditors, efficiency monitoring tools, network installers, and manufacturers of products ranging from temperature sensors to building components made from sustainable materials.

- $\quad$ Our ongoing search for transportation alternatives reduces our use of fossil fuels, cleans up the air, and has important lifestyle and health benefits.

- $\quad$ Livable, walk able, sustainable communities are more appealing to the rising generation of talent that we need to locate here.

- $\quad$ Progress on all of these fronts helps Southwest Florida achieve a goal of reducing emissions by $80 \%$ from 1990 levels by 2050.

Climate Prosperity also offers Southwest Florida the opportunity to add manufacturing jobs back into the mix, and to engage the full range of skills and talents in the community. The global competition will be intense, but by acting now we can capitalize on first mover advantage.

The new Southwest Florida Climate Prosperity Council should aim to prove we can turn our worst crisis into our greatest accomplishment yet, and provide a role model for the nation.

SWOT Analysis - We have identified some of the strengths and weaknesses internal to the Southwest Florida region, as well as external opportunities and threats that the region may be subjected to. 


\begin{tabular}{|c|c|c|c|}
\hline \multirow{13}{*}{$\begin{array}{l}\sum^{1} \\
\qquad \\
0 \\
0 \\
0\end{array}$} & \multicolumn{2}{|c|}{ INTERNAL } & \multirow{13}{*}{ 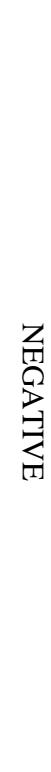 } \\
\hline & STRENGTHS & WEAKNESSES & \\
\hline & Florida's natural resources such as sun and the everglades & Lack of funding & \\
\hline & $\begin{array}{l}\text { Bountiful supply of unemployed labor force who are } \\
\text { willing to work }\end{array}$ & Lack of cohesive workgroup to promote project & \\
\hline & Desirable locale that has a strong draw for more residents & $\begin{array}{l}\text { Lack of central database to offer to those who may be } \\
\text { interested in the project }\end{array}$ & \\
\hline & No state income tax or city tax (Wise Geek, 2010) & & \\
\hline & High tourism & & \\
\hline & OPPORTUNITIES & THREATS & \\
\hline & Money saving options for those who choose to participate & Catastrophic events & \\
\hline & $\begin{array}{l}\text { Cost effective options for businesses and homeowners } \\
\text { alike }\end{array}$ & Hurricane probability & \\
\hline & Reduce green-house gas emissions & Flooding probability & \\
\hline & $\begin{array}{l}\text { Renewable energy options that can save our natural } \\
\text { resources }\end{array}$ & Lightening damage & \\
\hline & $\begin{array}{l}\text { To obtain external funding from different agencies through } \\
\text { Government funding to private or corporate grants }\end{array}$ & Occasional freeze damage & \\
\hline
\end{tabular}

\section{GETTING FROM CLIMATE CHANGE TO CLIMATE PROSPERITY}

\section{Confronting Climate Change}

Climate change is a problem that is affecting people and the environment every day. Greater energy efficiency and new technologies have the potential to reduce greenhouse gases and solve this global challenge. Today, our nation is addressing climate prosperity so that ecosystems, human life, and infrastructure can adapt into a more resourceful future.

Over the last few years, discussions with economists, businesses, and public sector leaders have shown that protecting the environment can be an economic driver for Southwest Florida. Climate prosperity offers Southwest Florida the opportunity to build on its traditional strengths and turn the climate challenge into a great economic opportunity. This region has the resources to build an innovative industry, create new jobs, grow the economy, and enhance the environment.

\section{The National Climate Prosperity Project}

Climate Prosperity, Inc. is committed to the creation of a low-carbon and prosperous American economy. In fall 2007, the Rockefeller Brothers Fund committed itself to the testing of the proposition that responding to climate change could represent not only an environmental imperative, but also an extraordinary economic development opportunity (Fleming, 2007). Key players in regional economic development - both private and public sector - are brought together to address the climate challenge and benefit the local and national economy at the same time.

In 2008, the Climate Prosperity Project selected pilot regions around the country to develop Climate Prosperity Strategies to assist in proving this concept. Southwest Florida was one of those pilot cities. Today, four of the eight original pilot regions have implemented programs toward achieving climate prosperity. These pilot regions are: Silicon Valley/San Jose, California, Portland, Oregon, St. Louis, Missouri, and Denver, Colorado. 


\section{Green Savings, Green Opportunity, And Green Talent}

Southwest Florida is a sustainability green leader, drawing on the regions resources as well as resources in the rest of the state of Florida. Building on the green assets of the state/region, the Southwest Florida Climate Prosperity Strategy is focused on creating important regional economic outcomes - Green Savings, Green Opportunity, and Green Talent.

GREEN SAVINGS All households, businesses, and governments can save money through increasing energy conservation, resource efficiency, and innovation. The following green savings initiatives make Southwest Florida more competitive.

Eco-Smart Communities: Eco-Smart Developments generate green savings through environmental preservation zones, energy efficient buildings and transportation, and solar energy generation. These communities both symbolize and exemplify Southwest Florida's commitment to environmental preservation, economic prosperity, and high quality of life. The leading example of Eco-Smart Development in Southwest Florida is Babcock Ranch, a city powered entirely by solar energy.

Babcock Ranch is a unique community that sought to preserve precious native Florida habitat, while offering a unique opportunity to create the world's most environmentally friendly, sustainable city. Fully $80 \%$ of the original 91,000-acre ranch will remain in its pristine and protected form in perpetuity as The Babcock Ranch Preserve (Babcock Ranch, 2009). In addition to the 73,000-acre nature preserve will be dedicated to natural greenways, parks and lakes, Babcock Ranch residents will be able to co-exist with nature in homes and businesses powered by the sun, transport via non-polluting electric vehicles, and explore miles of hiking and biking trails inside the community.

Hurricane/Energy Efficiency Retrofits: Southwest Florida has been identified by the National Weather Service as one of the most hurricane vulnerable areas of the United States. There is an opportunity for Southwest Florida to pioneer the creation of an integrated approach to hurricane and energy efficiency retrofits. Once established in Southwest Florida, this approach to integrated hurricane/energy retrofits could be exported to other regions that are at risk for hurricanes and need energy efficiency retrofits.

Climate Adaptation: Climate change has already caused the sea level to rise, which increases the danger of storm surges. Adequate climate protection strategies must be implemented for vulnerable areas to address the climate risks and develop climate adaptation strategies.

GREEN OPPORTUNITY A green economy will be based on a new generation of products and services all of which will create many new businesses and jobs across the entire value chain. Business, government, and community actions to reduce greenhouse gas emissions will also greatly expand producer and consumer market demand for green goods and services.

Solar Industry: Southwest Florida has a significant number of larger scale solar installations in process. For example, Florida Gulf Coast University has started construction on the 16-acre solar energy farm on the Florida Gulf Coast University campus that will produce 2 megawatt of energy to benefit the business community, the construction industry, and the general public.

Sustainable Agriculture and Ecotourism: Southwest Florida has a strong sustainable agriculture industry, with a significant number of organic farms, a network of 7 farmers markets, a number food stores and super markets featuring organic produce, and an export market to other regions of Florida and areas of the country. Additionally, there is a wide array of opportunities for ecotourism. To date, there are a large number of ecotourism businesses operating in the Southwest Florida region.

GREEN TALENT A new generation of green employment and entrepreneurial skills will help build the essential foundation for a more competitive and productive economy. The Green Talent Initiative will address the problems currently facing Southwest Florida - unemployment, the recession and climate change. In addition, 
improving the quality of life in localities through environmental and cultural sustainability will attract and retain a highly skilled workforce of talented people.

Green Jobs and Entrepreneurship Programs: There are several green job programs in existence in Southwest Florida. Green Entrepreneurship is another major aspect of the Southwest Florida Green Talent Strategy as top universities are using the green initiative to attract professors, students, and corporate partners.

\section{Achieving Climate Prosperity In Southwest Florida: Short-Terms Goals}

To achieve climate prosperity, Southwest Florida must generate short-term goals and actionable goals. Before the climate prosperity plan can be developed and translated into actionable goals and policies, a foundation of institutional, organizational and community capacity must be built. The climate prosperity foundation is built through identifying champions and lead organizations, assessing the community with sustainability planning, building upon current community assets, and developing a strong and unifying vision. Examples include adding solar heaters to sub divisions, investing in solar film for Southwest Florida schools, and involving prominent green companies, such as Storm Smart Industries.

The first short-term goal is to conduct a gap analysis for Southwest Florida. In short, the purpose of gap analysis is to identify the gaps between where Southwest Florida is today and where Southwest Florida wants to be in the future in regards to climate prosperity. The gap analysis process involves determining, documenting, and approving the variance between requirements and capabilities. The Southwest Florida gap analysis should focus on the following areas: land use, transportation, financing, public policy, market confusion, buildings, utilities, and cost competitiveness.

The second short-term goal is to create an action plan that defines the steps to implement the chosen goals and objectives. This action plan should describe the components of each proposed project and explain how those projects support the strategy, objectives, and goals of the overall Southwest Florida climate prosperity plan.

The third short-term task is to define the roles of the counties involved. In Southwest Florida, the six counties that support energy efficiency improvements are Collier, Lee, Henry, Glades, Sarasota, and Charlotte. These counties have existing commitments from both government and business on waste reduction programs, clean, convenient transportation, water conservation and irrigation system programs, and energy initiatives. Each county is also helping businesses improve their energy productivity. There is numerous state, regional, and local initiatives aimed at promoting adaptation, renewable energy and biotechnology.

The fourth short-term goal is to collaborate with the community organizations that are also engaging in the development of carbon reduction policies and effective solutions. For example, Southwest Florida universities, such as Florida Gulf Coast University and Edison State College are producing informative research on the environmental and economic impacts of climate change. Florida Gulf Coast University has a 2MW solar system, the second largest solar system located on a university campus in the United States. Additionally, Edison State College hosts the annual GreenFresh Expo, which incorporates workshops, presentations, and booths on sustainability, energy, and coastal protection alternative energy systems.

Climate prosperity in Southwest Florida benefits the environment, economy, and society. These short-term goals provide the framework to increase local economic growth, employment creation, and development initiatives within the context of sustainable development. In the near future, a joint collaboration should take place among leaders of the Southwest Florida Counties involved and champions from community organizations currently engaging in climate prosperity. Once a visioning process has taken place, specific goals, objectives, and strategies will define the Southwest Florida green community.

\section{THE OPPORTUNITY: SOUTHWEST FLORIDA IN CREATING A GREEN ECONOMY}

Southwest Florida has been able to successfully attract tourists, vacation home owners, and retirees to its region for a lot of years in the past and is expected in the future. Coastal economy of Florida in 2006 generated \$562 
billion and the tourism industry employed over 900 million people in Florida (Jordan, 2008) In 2006, Florida's coastal counties accounted for over $79 \%$ of the state's economic productivity (Jordan, 2008).

Everglades and Gulf Coast businesses add up to major sources of employment in the region. Both Everglades and Gulf Coast attractions are considered national and worldwide brands of the region and ranked high on lists of most preffered spots to visit in a lifetime. Abundance of sun, beaches, and land for agriculture and housing forms a fit environment for attracting new tourism, housing, and agriculture industries. These industries have been central for economic prosperity and responsible for economic concentration in the Southwest Florida region.

Global climate changes are adressed through governmental support in Southwest Florida. Busineses, government, and community adopt green initiatives and take actions to reduce greenhouse gas emissions. The efforts are vectored to augment producer and market demand for green products and services. The growing demand for these green economic driving elements is expected to spur green industries growth in the region.

State and regional organizations support region's climate prosperity strategy. Governor's Climate Action Team, Florida Solar Energy Center, Sustainable Florida-Collins Center, Florida Farm to Fuel Initiative, and Biofuel Association support sustainable change on state level. On regional level, support comes from Southwest Florida Branch of the Green Building Council, The Center for Environmental and Sustainability Education at Florida Gulf Coast Univeristy, Florida House, and five (eco-smart development, hurricane/energy efficient retrofits, green business partnership, climate adoption, and evironmental mitigation banking) county and city sustainability initiatives (Sustainable Systesms, 2009).

Southwest Florida's sustainable economy will be based on a new generation of products and services to support current and encourage development of new industries. Sustainable development will create many new businesses and jobs across the entire value chain in Southwest Florida. Manufacturing and production, marketing and distribution, and wholesale and retail trade industries are all expected to benefit from the sustainable regional development. In the future more green busineses are expected to arrive, evolve, and emerge to take advatantage of governmental incentives and benefits of various economic initiatives to promote sustainable development.

\section{Climate And Environmental Amenities}

Open areas of marshlands of Everglades, dry lands of former "grass river" areas, and abundance of sunshine all year create a suitable environment for solar energy companies, energy dependant businesses, and households industries to grow. Significant opportunities are expected to be open for green businesses in developing solar-powered Babcock Ranch city in Charlotte and Lee County and other expected projects. Along with development of appropriate housings and tourist attractions, new opportunities for ecotourism and ecoagriculture will emerge.

Southwest Florida's subtropical climate and environmental amenities of sun, ocean water, wind, and nature create opportunities and pose threats to economic development of the region in a duet. Most of the opportunities will come from creating suitable environment for inviting and creating businesses, providing people with higher living standards and affordable housings, and converting Southwest Florida communities to eco-friendly communities through multiple efforts of many interested parties to encourage educational and governmental incentive programs. Tourism businesses will benefit from more availability of locations to visit for tourists and attractive advertisings. Developing infrastructure will positively contribute to convienient travel and more efficient agriculture and trading.

The Sunshine state is already home for many retirees from the entire country, searching to settle in warm places near the Gulf coast. Many new job opportunities will appear once more babyboomers settle in Southwest Florida and more tourists come to the economically attractive region. Demand on hotels, attractions, other amenities and maintance will rise accordingly. The region's development, job attractiveness, and job availability would encourage youth to stay rather than move out from the region. A significant number of newcomers will contribute to creating jobs and job opportunities for young generation. Increasing employment should positively contribute to the region's sustainability strategy at large. 


\section{Economic Risk}

Authorities and local communities get increasingly concerned about economic stagnation, climate change, high risk of hurricanes, and their impact on Southwest Florida's low lying lands in relation to the sea level. The concern about environment gained more importance after the leak of an oil well in the Gulf of Mexico. Even the oil has not been officially declared to reach Southwest Florida Gulf coast, there are claims that it has been found on northern side of Florida. Striving for a sustainable change, governments seek for support to promote new ecofriendly industries to the region to expand region's economic development and protect the Gulf coast lands, Charlotte, Lee, and Collier County in particular, from adverse natural cause occuranes for years to come.

The impact of the residual oil hurt a multibillion tourism industry in Florida. The oil issue could negatively impact more than 900,000 Floridians directly employed in tourism (Sustainable Systesms, 2009). Threats are also expected from natural disasters, which are relatively common in the region. Storms of 74 miles per hour or higher can destroy newly built amenities. Thus, there should be plenty of room for future planning and attracting engineer jobs and engineers to develop hurricane stable materials and build reinforced or retrofit structures to ensure sustainability in a long run.

\section{Economic Challenges}

Before the hit of recent recession, Southwest Florida has experienced high rate of overbuilding and Florida overall was a low cost state. After the economic slump and housing collapse, prices have significantly risen, making it no longer the case. Public transit is not developed in Southwest Florida. The common mode of transportation in Southwest Florida remains moving by cars on street roads and highways. Undeveloped transit system poses a difficulty for frequent long and short distance commuters.

Southwest Florida has also low intensity of land development. In just three of six counties in Southwest Florida, 900,000 subdivided lots are registered as owned (Sustainable Systesms, 2009). Most of the land lots are undeveloped or underutilized. Such economically inefficient use of land makes assembly for larger scale mixed-use retail, commercial, and/or inudstrial development much more difficult. More than 10\% or 58,000 people are unemployed in Southwest Florida (Sustainable Systesms, 2009). Lee County has notoriously leading position in the country for foreclusures. In combination of high costs and economic difficulties pose significant development challenge in Southwest Florida.

\section{Economic Strategy}

Southwest Florida's primary economic development strategy is to focus on tourism and housing. The strategy is to encourage those people who visit the region to stay longer or even move in the region. Other leading economic clusters should focus on healthcare, agriculture, and retail. These industries should facilitate living in the region and support the primary strategy.

\section{SOUTHWEST FLORIDA'S GREEN PRINT PROSPERITY STRATEGY: OUR INITIATIVES AND INFRASTRUCTURE CAPABILITIES}

While many regions are looking for ways to reduce greenhouse gas emissions, Southwest Florida (SWFL) is in a position to both reduce emissions and grow new industries through our very own natural resources. In this era, Climate Prosperity" is an approach that "fits" how our region works. SWFL can generate substantial economic and employment growth by demonstrating that innovation, efficiency, and conservation in the use of all SWFL resources will be our best way to increase jobs, income, productivity, and competitiveness. 


\section{Strategic Framework For Action}

The strategy has two elements:

- $\quad$ Broaden the SWFL innovation infrastructure to make Southwest Florida the world's center for clean and green innovation

- $\quad$ Build a regional market for clean and green products and services through a series of action initiatives that bring together all of the elements of the habitat on a regional scale

The creation of a new leadership body, the Southwest Florida Climate Prosperity Council, will identify opportunities for action and provide coordination. Facilitated and supported by Joint Venture, the council will also track and report on the action initiatives using measures of climate protection and economic development. The Joint Venture will consist of members of the Southwest Florida Climate Prosperity Council and the present time members of the Hodges University Entrepreneurial Center.

Build Regional Market for Clean and Green Products and Services

\begin{tabular}{|c|c|c|c|}
\hline $\begin{array}{l}\text { Renewable Energy } \\
\text { - Streamline and standardize } \\
\text { permitting and inspections } \\
\text { - Expand the use of regional } \\
\text { public procurements } \\
\text { - Expand use of special } \\
\text { assessment districts to simplify } \\
\text { financing } \\
\text { - Simplify rebate application } \\
\text { process }\end{array}$ & $\begin{array}{l}\text { Building Efficiency } \\
\text { - Standardize green building } \\
\text { policies across the region } \\
\text { - Update existing buildings } \\
\text { for energy efficiency } \\
\text { - Trigger energy efficiency } \\
\text { audits on sale } \\
\text { - Ensure access to energy } \\
\text { efficiency for all }\end{array}$ & $\begin{array}{l}\text { Clean Convenient } \\
\text { Transportation } \\
\text { - Deploy charging stations } \\
\text { for electric vehicles } \\
\text { - Commit to public fleets of } \\
\text { very low/ zero-emissions } \\
\text { vehicles } \\
\text { - Support prototyping of } \\
\text { low/zero-carbon vehicles } \\
\text { using advanced } \\
\text { technologies } \\
\text { - Expand public transit } \\
\text { options }\end{array}$ & $\begin{array}{l}\text { Green Infrastructure } \\
\text { - Develop smart grid } \\
\text { zones to demonstrate } \\
\text { the potential } \\
\text { - Deploy smart meters } \\
\text { and make the data } \\
\text { available } \\
\text { - Integrate local and } \\
\text { urban power } \\
\text { generation with plug- } \\
\text { in infrastructure }\end{array}$ \\
\hline
\end{tabular}

Southwest Florida Climate Prosperity Council

\begin{tabular}{|l|l|l|l|}
\hline \multicolumn{1}{|c|}{ Innovation Production } & \multicolumn{1}{|c|}{ Regulatory Climate } & \multicolumn{1}{c|}{ Investment } & Land and Facilities \\
$\begin{array}{l}\text { - Provide incubation services } \\
\text { - Provide testing/prototyping } \\
\text { resources }\end{array}$ & $\begin{array}{l}\text { Expedite expansions for } \\
\text { green companies } \\
\text { - Conduct demonstration projects } \\
\text { state, federal policies }\end{array}$ & $\begin{array}{l}\text { Develop innovative } \\
\text { incentives } \\
\text { Secure public and private } \\
\text { giants }\end{array}$ & $\begin{array}{l}\text { Provide site location } \\
\text { assistance } \\
\text { high-cost tools }\end{array}$ \\
\hline $\begin{array}{l}\text { - Align training programs to needs of industry } \\
\text { - Tap federal, state, private funding for workforce development }\end{array}$ & $\begin{array}{l}\text { - Promote exports through trade missions } \\
\text { - Launch "buy local" program for green products }\end{array}$ \\
\hline
\end{tabular}


Grow Regional Base Of Clean And Green Industries

Emission Reductions

\section{MEASURING THE BENEFITS OF CLIMATE PROSPERTY}

- Air Quality

- Public Health

Green Savings

- Savings from efficiencies

- Savings for Renewable

\section{Green Opportunities}

- New Green and clean businesses

- Patents

- Venture capital investment

Green Talent

- New Green jobs

\section{Grow The Southwest Regional Base Of Clean And Green Industries}

The following elements of the framework are the "soft infrastructure" needed for economic growth Most of the elements are provided by public agencies and educational institutions, sometimes in partnership with community-based organizations that provide special expertise, leadership, and outreach.

Investment With any new technology, financing is vital not only for R\&D but through the commercialization process and widespread adoption of the new technology. Several cities are now testing a financing model that creates tax assessment districts to simplify the purchase of photovoltaic systems and more energy-efficient equipment.

Land and Facilities Much can be done on a regional level to encourage the agglomeration of clean technology companies. A number of cities are helping small and midsize businesses find good locations, and a few have supported the formation of business incubators to help new clean and green businesses succeed.

Promotion In order to further bolster the SWFL region's role as a clean technology capital, SWFL and its companies can be promoted internationally. Our cities and Chambers of commerce have launched green business certification programs and "buy local" programs for green products and services. Farmers markets, which help reduce Greenhouse gas emissions from imported foods are growing in popularity.

Innovation \& Production A key requirement for establishing Southwest Florida as the clean technology capital is being the source of cutting-edge research and development. Clean technology companies need access to the universities, national labs, and research centers in the Sunshine state, plus funding to help with converting unproven technologies into robust, marketable products. Local testing centers, such as Solar Illuminations of Cape Coral, speed time to market. Demonstration centers and prototype facilities with the latest equipment help startups conserve capital.

Workforce Demand is growing for skilled workers across an array of occupations in industries providing products and services that reduce pollution or improve resource efficiency. Work groups are partnering with community colleges and training centers to build a talented workforce that is productive and able to earn the kind of wages needed to live in a high-cost region (Sustainable, 2009).

Regulatory Climate Public policy can play an effective role in streamlining the wide spread adoption of new technology through project permitting, inspection processes, and expediting. Public procurements can 
emphasize the importance of solutions that emphasize the use of sustainable and renewable components. Efforts can also be taken to encourage the attractiveness of the region to clean technology companies.

\section{Build A Regional Market For Clean And Green Products And Services}

Through action initiatives we can leverage our innovation habitat to stimulate the growth of our clean and green technology companies, and converts to a sustainable, low-carbon, energy infrastructure. The following four areas of opportunity have come together as a result of numerous meetings with regional leaders in green public policy and experts in the fields of renewable energy, green building, transportation alternatives, and energy infrastructure.

The Climate Prosperity Council will review these areas of opportunity and develop action initiatives in each segment.

\section{Renewable Energy}

We have an array of solar technologies, manufacturers, and installers. There is work to be done on permitting, workforce development, financing, and tariffs. Homeowners and commercial building owners need help understanding how to buy and take advantage of photovoltaic and solar heating. Incentive and rebate programs need to be simplified and streamlined.

Utility-scale photovoltaic and hybrid systems are starting to come online. Our local government agencies need to look at available land and explore new partnerships with generators.

Wind today is limited to enormous towers isolated from communities. We need to explore smaller-scale systems that may make sense in urban environments without compromising the aesthetics we need to attract and retain a talented workforce.

\section{Building Efficiency}

Thanks to some earlier efforts, the patchwork of green building codes and ordinances is growing more consistent. But many of the requirements are deliberately loose and not enforced. We need to move quickly to tighten the rules and to train engineers, construction workers, and building inspectors on new, environmentally sustainable, energy-efficient materials and equipment. That is why Hodges University is trying to gain support of an Entrepreneur Center locally.

Home and business owners would welcome energy audits if they were free or cheap. The audits need to be accompanied by easy-to-use analysis of solutions, and information on rebates and subsidies. Those rebate programs need to be as simple as possible.

Buildings use water, an increasingly scarce resource in Florida and a concern for our agriculture growers, but certainly for our tourism industry to heat things up. Rooftop solar water heaters are common in countries where energy is expensive, but yet have little influence in SWFL's region except to heat some swimming pools and homes that can afford them. The technology exists to create water budgets for landscaping, and to connect the system to the Internet to minimize overwatering and there should also be a way of using our natural resources, such as the sun, as a source.

\section{Clean, Convenient Transportation}

Could Southwest Florida become the clean energy capital of the world? The competition will be intense, but we already have companies like Great Water Live Longer, Solar Illuminations, White Water Farms, Ecological Labs, and more who has initiated green ideas. We have seen many new trends of people buying and driving smart cars, hybrid cars in southwest Florida. 
Much can be done to transform travel by expanding public transit options, improving travel efficiency, and thoughtful land-use development. With public support, rail-based transit could grow in importance and accessibility. Within the next ten years, the federal government has approved a high speed rail from Orlando to Tampa, Florida and this could lead to the extension of it by going south, stopping in Fort Myers and Naples before ending in Miami. Employers can play a role in encouraging cleaner commute choices by paying for public transit passes.

Public agencies could further encourage the use of public transit by reducing ratios for parking spaces at stores and offices, and modifying general plans to allow people to work closer to where they live.

Bicycling and even walking can be encouraged through the construction of more bicycle lanes and storage facilities, and walkways that are safe and pleasant for school children.

\section{Green Infrastructure}

Utilities around the world are developing the concept of the "smart grid"- a combination of transmission lines and information network that allows for both the seamless integration of distributed and renewable sources of electricity, and customer participation in managing energy use. There should be a pilot installation in Southwest Florida that draws on local information technology companies and research centers such as Florida Gulf Coast University and other institutes working toward a common goal, to name just two possibilities. It would be beneficial to Southwest Florida to add an entrepreneur center at Hodges University to further enhance this infrastructure.

To make good decisions about energy efficiency, consumers and business people need more information about prices and usage. Our utilities should start deploying "smart meters" to meet that need. With all our measurement and information technology companies, Southwest Florida should be a priority region for deployment.

Construction of the smart grid and installation of smart meters is going to require a trained workforce. With the support of our labor forces, SWFL could become the southern regional center for training of construction workers. Here in SWFL, there have already been some new emerging construction companies eager to support going green by offering energy saving materials to install for consumers, just need our local support to assist them.

\section{MEASURING OUTCOMES AND BENEFITS}

Success needs to be measured on the basis of both benefits to the environment and growth in the economy. The following four categories of outcome measures provide a framework for discussion by the Climate Prosperity Council. Joint Venture's Index of Southwest Florida needs to report on some of these areas. The Council may decide to issue a separate report to go into additional detail.

Emissions reductions: Using tools from ICLEI — Local Governments for Sustainability (an international organization that helps local governments inventory GHG emissions) and data from the Bay Area Air Quality Management District, we will be able to track greenhouse gas emissions by source, including electricity, natural gas, transportation, and renewables.

Energy savings: Using less energy means spending less money. We will report these savings and estimate the impact on the local economy.

Green opportunity: Climate change presents new business opportunities as residents, businesses, and governments must make adjustments in the kinds of products they purchase and the energy and natural resources they consume. Growing business opportunity can be tracked by business growth and venture capital investment in specific green business activities. Further, tracking patent registrations in clean technology provides an indication of future business opportunities.

Green talent: The growth in jobs and training programs related to green business activities is a direct indicator for the transformation of the green economy and for Climate Prosperity. 


\section{THERE ARE THREE FORMS OF CAPITALISM}

The sustainability revolution is based on the fundamental recognition that there are three forms of capital essential to the creation of genuine prosperity. In addition to economic capital (financial and manufactured), there are two other forms - natural and social.

Natural Capital: The economy operates within design limits inherent in the natural environment. If the economy disrupts the environment it disrupts itself, at great financial cost to society and to individual businesses. Historically corporations have often treated natural capital like a "free" asset to be exploited on a first come, first serve basis. As a result, enormous resources have been lost that were once, in fact, provided for free by intact ecosystems. Conversely, the sustainability revolution recognizes the economy's dependence on the environment for fresh air, clean water, climate stability, renewable energy, and a thriving eco-system. Businesses need to derive value from the eco-system without disrupting it. In fact, the human economy is really a subset of the natural "economy" rather than vice-versa. As the sustainability revolution proceeds, true cost pricing and true cost accounting to value major contributions of the natural world are emerging.

Social Capital: A prosperous economy depends on a stable society with an effective workforce. The economy threatens its own foundations if it disrupts society by allowing an extreme gap to emerge between the very wealthy few and the rest of the population or by inadequately supporting society's ability to ensure public safety, an effective educational system, a well trained workforce, and quality affordable health care. At the same time, a prosperous economy contributes to a stable society by creating the jobs, the opportunity for productive work, and the income that people need to live satisfying lives. The sustainability revolution recognizes the profound contribution of social capital to a prosperous economy and builds social capital by paying its fair share of taxes and making investments in a healthy society in many other ways.

Economic Capital: Economic Capital is most widely understood by economists and policy makers. It includes the finance, manufacturing, production, and physical infrastructure (energy, water, transportation, and information). Sustained economic prosperity requires that both the private sector and the public sector operate according to sound financial principles. Private and public players need to live within their means and continuously reinvest in their Economic Capital. The real estate meltdown and the resulting great recession is an example where economic policies led to a destruction of Economic Capital (Cleveland \& Nixon, 2010).

\section{WHAT THE HODGES UNIVERSITY ENTREPRENEURSHIP CENTER WOULD REPRESENT}

\section{Here Are Some Strong Reasons To Start An Entrepreneur Center}

- $\quad$ Creating the Hodges University Entrepreneur Center plays an important role in fostering of University spin-offs by encouraging further technology development through sponsored research activity at the center. Until a spin-off is able to finance its own research space, the Entrepreneur Center acts as a "virtual incubator" for these fledgling companies

- $\quad$ The center would not only provide opportunities to enhance spin-offs, but also speed up the process of creating successful commercial enterprises by providing "virtual incubator projects" to companies

- $\quad$ Provide advisory session consulting from experts, coaching, and mentoring. It would communicate a "strong entrepreneur culture" for the Southwest Florida region

- $\quad$ The center would support early stage start up business ideas from students and organizations that don't know how to get started

- $\quad$ Form strong alliances with local committees and organizations to encourage job creation that would add value to the Southwest Florida community and the economy

- Hodges University Entrepreneur Center will also provide students with the ability to practice entrepreneurship and business develop skills while attending it creates Southwest Florida's leaders of tomorrow 


\section{Testimonials From Students And Local Businesses Supporting The Center}

Michael Wenger and Bret Bonnet couldn't wait to start their own business. They launched Quality Logo Products (www.qualitylogoproducts.com) in 2004 while they were still students at North Central College.

The entrepreneurs operate an online store that markets 13,000 promotional products such as stress balls, pens, T-shirts, drink coolers, coffee mugs and golf balls. Their clients include a wide array of national and international businesses and nearly ever Fortune 500 company.

Wenger double majored in management and entrepreneurship when he graduated from North Central College in 2004 and Bonnet majored in entrepreneurship and small business, graduating in 2005.

Bonnet's advice to aspiring entrepreneurs is to get started even before graduation. "Save your money," he says. "Take that money and at least give [your idea] a shot. It's your only chance to venture out with the risks being what they are. Every day that goes by is a missed opportunity."

After submitting a detailed business plan, the pair received an interest-free loan from the Coleman Foundation to start their enterprise. "They're my best success story," said Gary Ernst, Coleman Foundation Professor of Entrepreneurship and Small Business at North Central College.

Adam Blake has been investing in residential real estate since he was a freshman at TCU - buying properties that he then rented to students to help pay his way through college. When he branched out to commercial real estate, the Neeley Entrepreneurship Center at TCU put him in touch with a successful developer who went over the numbers and helped him structure the deal. A fraternity brother provided capital. In 2009, Atlas Properties was ranked \#123 in the Inc. 500 Fastest Growing Private Companies in the U.S. With three-year growth of 1,412\%, Atlas Properties also ranks 11th in Texas, and ranks as the 2nd fastest-growing Real Estate Company nationwide while having the youngest $\mathrm{CEO}$ on the list.

\section{Phil Brown | CEO \& Co-Founder | Conflicts Authority, Inc.}

"The Entrepreneur Center @NVTC was extremely valuable to my start-up company. We had initially contacted the Entrepreneur Center to help us in business planning and fund raising efforts. The Entrepreneur Center gladly arranged advisors to assist the management team in the development of our business plan. The Entrepreneur Center and NVTC have also been a great resource for networking with local entrepreneurs and established business leaders. I strongly recommend small and growing companies to take advantage of the Entrepreneur Center's services."

\section{Janet Miller | President | Search Mojo}

"As a recent MBA graduate from Georgetown University, I learned all of the practical, technical, and functional skills to succeed in business during my two years of graduate training. However, I consider being part of the Entrepreneur Solutions program at NVTC as a type of post-graduate training and development where I can attain all of the intangible skills that one doesn't learn in business school." (NVTC, 2008).

\section{WHAT THE HODGES UNIVERSITY ENTREPRENEURSHIP CENTER WOULD REPRESENT}

The Entrepreneur Center's mission is to create entrepreneurial leaders and organizations in all segments of society, throughout Southwest Florida. The center will provide the Hodges University of students, alumni, and professionals with the knowledge and contacts that enable them to reach their entrepreneurial objective of designing and launching successful new ventures based on innovative concepts.

Our vision is to be recognized as a leader in entrepreneur research, education, and outreach, as well as to be ranked among the nation's top entrepreneurship centers.

One goal of the center is to serve as a clearinghouse to match promising innovative companies from Southwest Florida with established firms, seeking to grow their product portfolio through co-venturing agreements. 
By merging innovative ventures with co-venturing partners it will be able to develop their operations to the next level. This goal will focus on specific Southwest Florida industries such as:

- $\quad$ Agriculture and water quality

- $\quad$ Biotechnology, health and pharmaceutical

- $\quad$ Consumer products

- $\quad$ Energy and green technologies

- $\quad$ Entertainment

- Information and communication technologies

- $\quad$ Tourism and coastal development

- Transportation Improvements

If approved would set up a website to create an investor or company profile for funding. To start setting this center up we have to identify the necessary resources that will support the center, which will consist of Hodges University resources, Regional resources, Entrepreneur resources, Tools, and funding from grants available from foundations.

The capital involved in this venture will depend on the type of program offered by the University, the courses that would justify the design in which the center intends to accomplish for an entrepreneurial degree or certificate, the structural size of the meeting place, workshops, conferences, and mentor services needed.

Here are some of the courses that are offered by FIU and should be considered in being implemented at Hodges Entrepreneur center that will produce solid results for the Entrepreneurial program.

\section{Entrepreneurship Track}

The Entrepreneurship Track is designed for business students interested in developing new business initiatives and in acquiring self-reliance in the business world. This curricular is a seven course, 21 credit hours program.

Students must take the following required courses ( 6 credit hours):

- $\quad$ MAN 4113 Entrepreneurship

- $\quad$ MAN 4110 Business Plan Development (Pre-requisite MAN 4113 or equivalent) and five (5) of the following elective courses (15 credit hours):

- $\quad$ AMH 4373 Entrepreneurs in the US

- $\quad$ AMH 4375 Technology \& American Society

- $\quad$ MAN 4117 Product Development and Innovation

- $\quad$ MAN 4142 Intuition in Management

- $\quad$ MAN 4364 International Entrepreneurship

- $\quad$ MAN 4153 Social and Nonprofit Entrepreneurship

- $\quad$ MAN 4932 Professional Development Module

- $\quad$ HFT 4292C Entrepreneurship in Hospitality and Tourism

- $\quad$ MAN 4802 Small Business Management

- $\quad$ MAN 4864 Family-Owned Businesses

- $\quad$ MAR 4025 Marketing of Small Business Enterprises

\section{Minor in Entrepreneurship}

Non-business students must take the following required courses (fifteen credit hours) to obtain an entrepreneurship minor: 
- $\quad$ GEB 4113 Entrepreneurship (or cross-listed course)

- $\quad$ GEB 4110 Business Plan Development (or cross-listed course, pre-requisite GEB 4113 or equivalent)

Plus three (3) of the following elective courses ( 9 credit hours):

- $\quad$ ACG 3024 Accounting for Managers and Investors

- $\quad$ AMH 4373 Entrepreneurs in the US

- $\quad$ AMH 4375 Technology \& American Society

- $\quad$ GEB 4117 Product Development and Innovation (or cross-listed course)

- $\quad$ MAN 4142 Intuition in Management

- $\quad$ MAN 4802 Small Business Management

- $\quad$ MAN 4864 Family-Owned Businesses

- $\quad$ MAR 4025 Marketing of Small Business Enterprises

\section{Entrepreneurship Certificate} hours):

To obtain a certificate in entrepreneurship, students must complete six of the following courses (18 credit-

- $\quad$ MAN 4113 Entrepreneurship (or cross-listed course)

- $\quad$ MAN 4110 Business Plan Development (or cross-listed course)

Plus four (4) of the following courses (12 credit hours):

- $\quad$ ACG 3024 Accounting for Managers and Investors

- $\quad$ AMH 4373 Entrepreneurs in the US

- $\quad$ AMH 4375 Technology and American Society

- $\quad$ MAN 2011 Introduction to Business

- $\quad$ MAN 4117 Product Development and Innovation (or cross-listed course)

- $\quad$ MAN 4142 Intuition in Management

- $\quad$ MAN 4364 International Entrepreneurship

- $\quad$ MAN 4932 Professional Development Module

- $\quad$ MAN 4153 Social and Nonprofit Entrepreneurship

- $\quad$ HFT 3210 Fundamentals of Management in the Hospitality Industry

- $\quad$ HFT 4292C Entrepreneurship in Hospitality and Tourism

- $\quad$ MAN 3025 Organization in Management

- $\quad$ MAN 4802 Small Business Management

- $\quad$ MAN 4864 Family-Owned Businesses

- $\quad$ MAR 4025 Marketing of Small Business

The next step would be to accomplish a corporate sponsor that the center will seek multi-yearly or annually for underwriting specific programs and activities, especially activities that provide outreach to the general entrepreneurship and business communities.

Then the center will need to establish an advisory council, which would be a distinguished group, or individuals who would be involved in setting the strategic direction of the entrepreneur center.

One of the most important processes here to point out is the involvement of local leaders and companies who really desire to improve the economic well-being of Southwest Florida (Fernandez, 2010). 


\section{The Following Guidelines Are For Funding Resources And Finding Grants}

A funder's guidelines will tell you what to include in a grant proposal for its organization. Here are some standard grant outline's information needed (http://www.mcf.org/nonprofits/successful-grant-proposal):

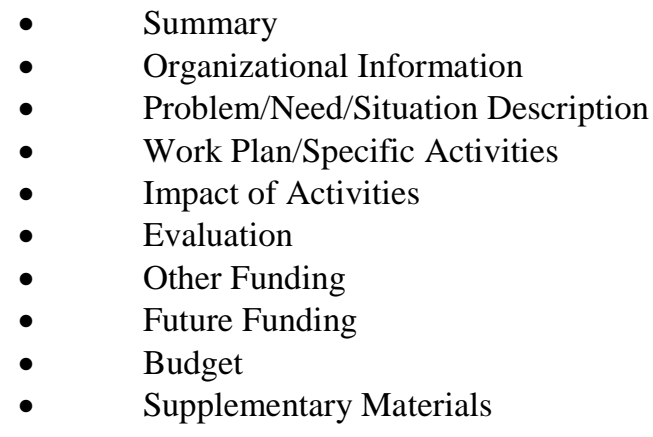

The Kauffman Foundation is an organization, which reflects the mission, vision, and direction that the Hodges University's Entrepreneurship Center wants to implement in resourcing Southwest Florida with entrepreneurs. Kauffman funds organizations that have a passion for education and entrepreneurship and they are always looking for opportunities to advance promising national programs that will leverage entrepreneurship which inspires the foundation to give additional funding and resources if qualify.

The Kauffman foundation grants are limited to programs and/or initiatives that have significant potential to demonstrate innovative service delivery, in support of education and entrepreneurship such as what Southwest Florida is in the process of accomplishing. The Kauffman foundation does not impose deadlines for funding or establish limits on funds.

Here are some examples of Universities and industries that have received funding from the Kauffman foundation:

- University of Minnesota, industry giants; $3 \mathrm{~m}$ and Cargill, along with the Kauffman foundation team up to tackle energy challenges

- $\quad$ Franklin Olin College of Engineering, Inc. was approved for a grant on January 1, 2010 for $\$ 50,000$ dollars

- $\quad$ Florida International University which is a part of our east coast Florida regional and who has a similar program was granted in 2003 for the start-up of the entrepreneurial program received $\$ 3$ million in grants from the Kauffman foundation to support entrepreneurial activities on a multi-disciplinary, university basis

- Still in 2010 the Kauffman foundation provides monies to 35 professors who fosters entrepreneurial activities up to $\$ 15,000$

\section{Kauffman Proposal Review Process}

We will honor your request by responding to all letters of inquiry. All letters are screened to determine if they relate to the Foundation's funding priorities, and a response will be sent. The route a grant proposal takes through the Foundation depends on the size of the investment, how closely it aligns with the Foundation's goals and whether funding is available. At this preliminary stage, we discourage personal visits to the Foundation by prospective grantees. Along the way during the grant review process, we may contact the organization to clarify the request.

Letters of inquiry that meet our initial criteria are reviewed in greater depth. However, the review process often takes several weeks to complete. If a grant request falls within the Foundation's programming interests and guidelines, and if the Foundation decides to further consider that request, we may ask the organization to develop a more detailed proposal. We also may respond to requests by approving or declining a proposal as it is submitted, or request clarification and/or offer technical assistance. Organizations selected to receive a grant will be expected to 
provide an Internal Revenue Service tax classification letter (Kauffman, 2010). Until you receive official notification that Kauffman is going to consider the grant. Do not fill out the application that can be found at their website. Ewing Marion Kauffman Foundation, 4801 Rockhill Road, Kansas City, MO 64110-2046.

For more information on funding and grants go to these Internet resources:

$\underline{\text { www.mcf.org/mcf }}$

www.kaufman.org

www.myflorida.com

$\underline{\text { www.climatebonds.net }}$ www.foundationcenter.org

www.eredux.com/states/state gov www.energysavers.gov/financial

There are many other University's and resources that would conform the request for Southwest Florida to move forward with this vital project. For example: The University of New Hampshire has developed a college facility powered by garbage- www.parade.com

Like the University of Utah the people of Southwest Florida's community and businesses need to come together as a team and develop ideas to sustain our future economically through these type examples of initiatives and not put it off until tomorrow thinking someone else will fix our future. See below:

The Office of Technology Venture Development bridges the gap between University research and Industry while acceleration the commercialization process. The map below (Fig. Chart 1) explains more about how Tech Ventures can help move your project along.

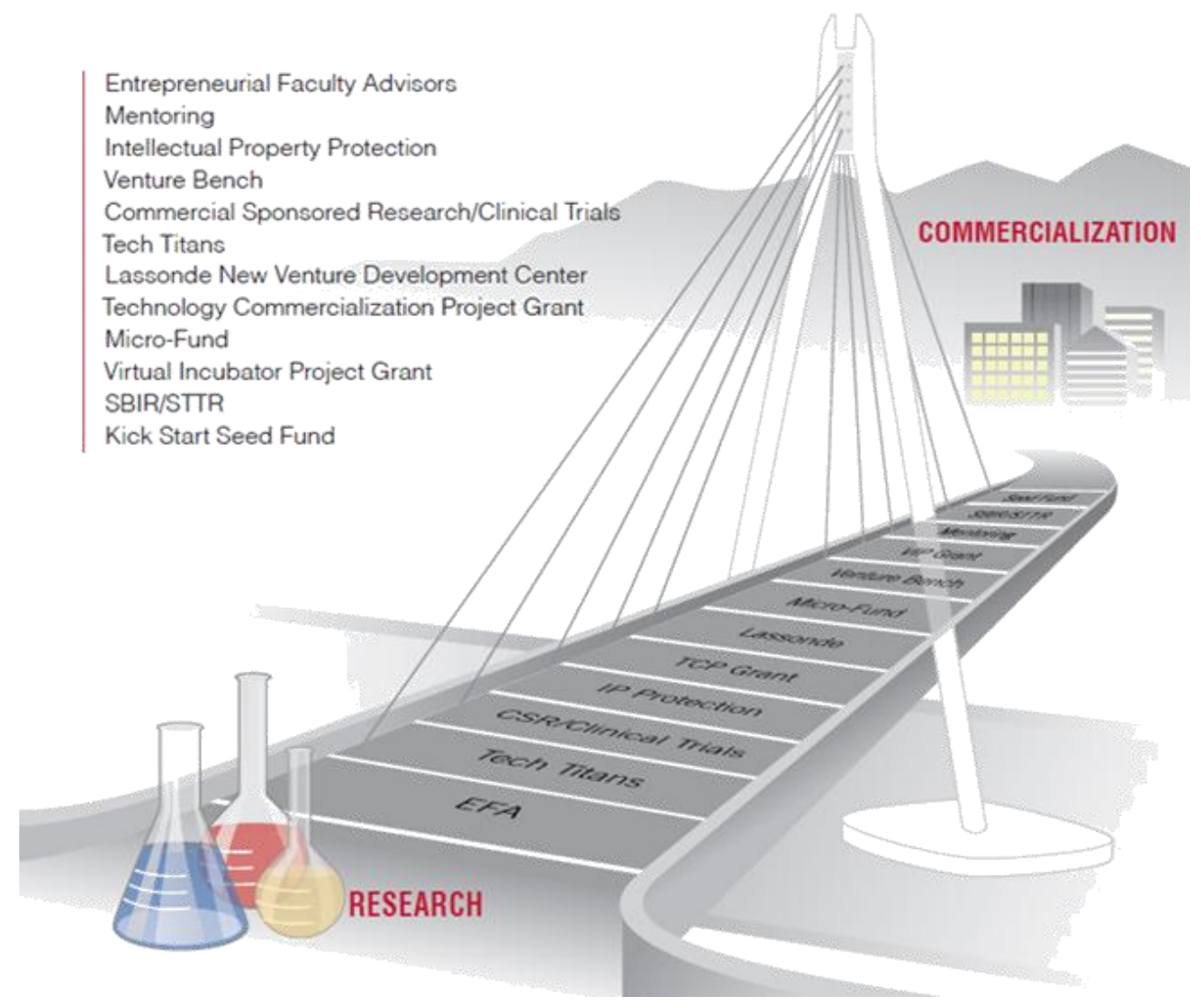

Fig. Chart 1. See Appendices for further information on Terminology 


\section{NEXT STEPS: THE CLIMATE PROSPERITY COUNCIL}

An overarching vision is needed to kick off the climate prosperity effort. From this vision different mission statements could be derived as to what kind of general efforts need to be broadly considered to affect the vision. From the mission statements high level goals and objectives could be developed for both short-term tactical wins and long term strategic success. A gap analysis would have to be performed to identify the difference between where we are today for any goal or objective and where we want to be in the definable future. From these gaps we will develop strategies that will need to be developed and implemented to close the gaps. Feedback from the implementation of these strategies would help to reshape the future planning cycles.

More attention has to be paid to developing infrastructure and transit systems in Southwest Florida to facilitate transportation and speed up developing projects. Projects have to be selected with taking youth in mind. More jobs have to be secured for youth to enhance career possibilities that would encourage youth to stay rather than leave the region. Comprehensive tax system has to be created to attract green businesses. Incentives should be offered to settle, protect and develop the region.

Additionally, there could be increased funding and extensive tax incentives and outright grants to encourage renewable energy projects, energy savings and green jobs provided by federal funding. An example is funding grants for development of renewable energy facilities.

Short-term goals are needed to immediately create industries and employment opportunities. Without short-term goals this is just another grand plan like so many that have gone before.

\section{AUTHOR BIOGRAPHIES}

Katie Rhodes was born and raised in Aurora, OH and graduated from Aurora High School in 1999. Katie attended Indiana University her freshman year, and then transferred to The Ohio State University in 2000. She graduated in 2003 with a Bachelor of Science in Education. In Fall 2007, Katie was accepted to Hodges University in the Master of Business Administration program and is expected to graduate in June 2011 with a 4.0 GPA. She is employed with Hodges University as a Financial Aid Officer. In her free time, she enjoys exercising, spending time with family and friends, and is very dedicated to her career and school.

John Avola graduated from the University of Central Florida with a Bachelor of Arts in advertising and public relations. In 2008, he enrolled at Hodges University to pursue a master's degree in business administration and has recently completed his MBA with a 4.0 GPA. While attending graduate school, John worked full time for Produce for Kids, a philanthropic marketing company. He has helped accomplish a company milestone of reaching $\$ 2.5$ million in donations for children's non-profit organizations. Personal achievements include University of Central Florida Communications Student of the Year and multiple National American Advertising Federation Awards.

Frank Blake is from New York State and after graduating from high school went in the military. Frank attended, college at San Diego State studying abroad in Southeast Asia for almost two years before going back to the United States. He decided to leave the military to work in the transportation industry. In 1999, he attended International College, now Hodges University, and graduated with a Bachelor's Degree in business. In 2009, Frank returned to Hodges for a Master of Business Administration. Frank is now considering a PhD. He hopes to one day start a business and be a contributor to the economy.

Tammy Fiedler is a recent MBA graduate from Hodges University. She has worked the last 6 years in the Finance department at Chico's FAS, Inc. headquarters in Fort Myers, FL. On September 13, 2010, Tammy will start a new career with the IRS and is looking forward to this big change in her life. She has also been married for a little over 3 years and is excited to start a family in the near future. Tammy plans to live in Fort Myers for the next few years.

Volodymyr Zakhvatayev was originally born in Ukraine. Volodymyr is an international MBA student at Hodges University. His educational background is diverse as he moved from state to state before settling to receive higher education. Volodymyr received his Associate of Arts in Spokane Community College in Spokane, Washington and 
Bachelor's degree from Cleary University in Ann Arbor, Michigan as Summa Cum Laude. He also studied in Edmonds Community College in Edmonds, Washington, where he received his English as Second Language (ESL) graduate certificate, and Eastern Washington University, where he started his Bachelor's degree studies.

Dr. Joseph Heinzman, Jr. is originally from central Pennsylvania where most of his relatives still reside. Dr. Heinzman was the Director of the Hodges MBA/MPA Program until July 2010 and is now the Campus Dean of Business and Management at Colorado Technical University in Colorado Springs, Colorado. He received a BS degree in political science and accounting from Weber State University in Ogden, Utah, a MBA from Florida Tech in Melbourne, Florida and a DBA from Nova Southeastern University the Huizenga School of Business and Entrepreneurship in Ft. Lauderdale, Florida. He spent 22 years in Aerospace business management and 8 years in aerospace information technology management before retiring in 2004. He taught at Valencia State College as an adjunct business professor from 1993 to 2004 and served from 2004 to July 2010 in many positions in the Johnson School of Business at Hodges University up to and including being the Director of the MBA/MPA Program. Dr. Heinzman left Hodges in July 2010 to be the Campus Dean of Business and Management at Colorado Technical University in Colorado Springs, and Pueblo Colorado.

\section{REFERENCES}

1. Babcock Ranch. (2009) Community life. Retrieved 2010, August 11 from www.babcockranchflorida.com

2. $\quad$ Center, P. 1. (2009). The Pierre Lassonde Entrepreneur Center. Retrieved 2010, 20-June from www.lassonde.utah.edu.

3. Cleveland, J., \& Nixon, J. (2010, June). Sustainable Economic development. Economics , 25, 31-40.

4. $\quad$ Fernandez, I. B. (2010, 8-June). Eugene Pina and Family Entrepreneur center. Retrieved 2010, 11-July from www.entrepreneurship.

5. Fleming, R. (2007) Climate Prosperity, Inc. Retrieved 2010, July 20 from www.climateprosperityproject.org/index

6. Harp, R. (2009). Southwest Florida Delegation Participates in National Climate Prosperity Project. Retrieved on June 12, 2010 at http://www.swfrpc.org/content/PR/CPP_PR_022609.pdf

7. Jordan, Marguerite. (2008). Florida's Oceans and Coasts Contribute Billions to Florida's Economy. Florida Department of Environmental Protection (FDEP). Retrieved on August 12, 2010 from FDEP website: http://www.dep.state.fl.us/secretary/news/2008/10/1001 02.htm

8. $\quad$ Kauffman, E. M. (2010, 1-January). Kauffman Foundation. Retrieved 2010, 21-June from www.kauffmanfoundation.org.

9. NVTC. (2008). testomonials of the Entrepreneur Center in Northern Virginia. Retrieved 2010, 17-July from www.nvtc.org.

10. National Association of Counties and Trust for Public Land. (2010). Conserving land for people. Retrieved on August 17, 2010 from http://www.tpl.org/

11. Sustainable, S. (2009, June). southwest Florida climate prosperity project. Retrieved 2010, 18-June from www.globalurban.org.

12. Sustainable Systems, Urban Sustainability Associates, and Global Urban Development. (2009) Southwest Florida Climate Prosperity Strategy. Global Urban Development (GUD). Retrieved on July 20, 2010 from GUD website: www.globalurban.org/Southwest\%20Florida\%20Climate\%20Prosperity\%20 Strategy.pdf

13. The United Nations Environment Program. (2010). The green economy initiative. Retrieved on August 17, 2010 from http://www.unep.org/greeneconomy/

14. Utah, U. O. (2005). Accelerating Commercialization. Retrieved 2010, 31-July from www.techventures.utah.edu.

15. Wise Geek. (2010). Do All States Have a State Income Tax? Retrieved 2010, August 11 from www.wisegeek.com/do-all-states-have-a-state-income-tax.htm 


\title{
APPENDICES
}

Entrepreneurial Faculty Advisors - (EFA) can offer personal assistance to new faculty entrepreneurs at various stages of company conceptualization, start-up, funding, product launch, business development, and growth.

\begin{abstract}
Mentoring - is a relationship in which one person (the mentor)--usually someone more experienced, often more senior in an organization--helps another (the learner) to discover more about themselves, their potential and their capability. It can be an informal relationship, where an individual leans on someone else for guidance, support and feedback, or a more formal arrangement between two people who respect and trust each other. Here are some of the advantages to becoming a mentor at the Entrepreneurial Center:

- $\quad$ As a development process, mentoring has advantages for the mentor, the learner and the organization.

- $\quad$ For the organization, mentoring offers:

- A means of supporting succession planning, and the maximizing of human potential better staff retention levels and recruitment prospects

- Improved communication and a means of acclimatizing employees to the organization's culture

- $\quad$ A cost-effective way of providing personalized development

- $\quad$ For the mentor mentoring offers:

- Increased job satisfaction, sense of value and status

- $\quad$ The opportunity to help and guide others in their career development
\end{abstract}

Intellectual Property Protection - Intellectual Property Protection is a product of the intellect that has commercial value, including copyrighted property such as literary or artistic works, and ideational property, such as patents, appellations of origin, business methods, and industrial processes.

Venture Bench - Venture Bench could be an Entrepreneur Center accelerator created by the Technology Commercialization Office that provides a suite of services for its technology-based companies. The Entrepreneur Center could have a long history of success in creating companies and creating new start-ups from its research-based inventions. This path to success can be long and challenging and Venture Bench provides new companies the support and expertise to shorten this time frame.

Commercial Sponsored Research/Clinical Trials - Technology Commercialized Program would be sponsored by the Entrepreneur Center of Research Foundation, which would support research in all areas of technology including medical devices, biomaterials, immunodiagnostics, drug design and development, etc. The emphasis is on developing novel, nearcommercialization technologies.

The Entrepreneur Center would develop a history of forming strong alliances with companies to develop new technologies that add value to our community and the greater general public. The Commercial Sponsored Research team would be here to help you make history. Our job would be to nurture effective and lasting partnerships by matching your research interests with our proven research capabilities.

We invite you to explore the benefits of working with the Entrepreneur Center team. Whether you are looking to expand your current research portfolio, or want to get a new idea off the ground, we can help. As our industry partners you could capitalize on the highly specialized knowledge and innovative talent the center has to offer.

Tech Titans- Tech Titans assists in aligning overall corporate business direction with IT, providing business case definition and tangible ROI for technology investments. We integrate business strategies with enterprise applications offering optimal functional alignment. Here are some supportive reasons to consider this:

\section{Value Proposition}

- Thought leadership for strategic business transformation

- Integrate business strategies with enterprise solutions offering optimal alignment with overall business direction

- Develop process centric, risk sensitive, sustainable compliance framework for performance

- $\quad$ Business case definition and establish value proposition for outsourcing opportunities

- $\quad$ Business case definition and tangible ROI for IT investments 
Offerings (Cleveland \& Nixon, 2010)

$\begin{array}{ll}\text { - } & \text { EPM and ERP Strategy } \\ \text { - } & \text { IT Strategy Planning and Roadmap } \\ \text { - } & \text { Change Management Strategy } \\ \text { - } & \text { Adoption \& Training Strategy } \\ \text { - } & \text { Software Package Selections } \\ \text { - } & \text { Health Checks } \\ \text { - } & \text { CIO Advisory Services } \\ \text { - } & \text { Outsourcing Evaluations } \\ \text { - } & \text { Readiness Assessments }\end{array}$

Capabilities

- $\quad$ Enterprise Performance Management (EPM) Deployment Planning and Road mapping

- $\quad$ Enterprise Resource Planning (ERP) Deployment Planning and Road mapping

- $\quad$ Portfolio Management

- Organizational Assessments

- $\quad$ Advisory Services

- $\quad$ Change and Program Management

- $\quad$ Project Management

- $\quad$ Organizational Design and Development

- Business Process Re-engineering

- Multi-functional Operational Excellence

- $\quad$ Industry \& Domain Expertise

Lassonde New Venture Development Center - This is an example of an Entrepreneur Center dedicated to The University of Utah.

Technology Commercialization Project Grant - the Foundation will support research projects that have strong potential for generating invention disclosures, patents, licensing and product commercialization in the short term. Thus, the Foundation will fund high-risk, fast track research in order to generate private investment for further development within a two-year period.

Applicants would have to clearly indicate the economic potential of the expected research results and identify a potential partner for subsequent commercialization.

Micro-Fund - Is a new small-scale funding opportunity. It would exist to enable researchers at the Entrepreneur Center to develop an existing technology to a stage where it is attractive to third parties for larger scale commercial development or licensing. The Technology Commercialization Office would sponsor these grants. There are no deadlines for these grants, they are open-submission.

\section{Criteria}

The Micro-Grant has been developed to support researchers working with technologies that need a small amount of research to develop first or second generation prototypes or that needs proof-of-concept data and experimentation results. Micro-Grant awards, which will be in the amount of $\$ 1,000-\$ 5,000$ depending on need, are available to all Faculty for the development of technologies that meet the following conditions:

1. The technology is the subject of a disclosure, which has been made to the Entrepreneur Technology Commercialization Office.

2. The technology can be developed to a stage where it is more likely to attract larger scale funding or a licensee within 6 months and within the limited budget of the award.

Virtual Incubator Project Grant - a VIP will consist of a "research voucher" granted to qualify Entrepreneurial centers spinoffs. The spin-off up to $\$ 50,000$ credit for sponsored research conducted at the Center. The research activity will be directed to the further development of technology licensed from the Center. The rewarding foundation group will sponsor these vouchers by transferring funds to the Entrepreneur center to cover the credit when the voucher is exercised. There will be no overhead charged to the voucher; therefore the full voucher will go towards research at the Center. Also, the foundation group will grant 
the spin-off an option to license any new intellectual property created in the performance of the contract. The Center will receive, in exchange for this voucher, equity from the spin-off equaling $2 \%$ of the spin-off company.

The intent of the VIP awards is to provide a funding opportunity in the R\&D gap between company inception and seed investment in order to: (a) accelerate the research and development cycle for Entrepreneur center spin-offs so that product will reach the market more quickly than without the award, and (b) encourage more Center spin-offs to reach commercial success.

Small Business Innovation Research (SBIR) is a highly competitive program that encourages small businesses to explore their technology potential and provides an incentive to profit from its commercialization.

Small Business Technology Transfer Research (STTR) stimulates and fosters scientific and technological innovation through cooperative research and development carried out between small businesses and research institutions. These Entrepreneur centerbased researchers, by joining forces with small companies, can spin-off their commercially promising ideas while remaining primarily employed at their research institutions.

If further development of a product based on your invention is necessary, and applications are appropriate, development funding via SBIR/STTR grants should be pursued.

The SBIR and STTR Programs are federal initiatives that provide over 2.5 billion in grants and contracts each year to small businesses and start-up companies to develop new products and services based on advanced technologies.

Kick Start Seed Fund - is a startup that funds other startups. Its mission is to kick-start companies in the South West Florida Region by aligning technology creators, industry, entrepreneurs, and follow-on capital sources behind the funding and mentoring of seed investments with tremendous potential (Utah, 2005).

\section{SOUTHWEST FLORIDA GREENPRINT KEYWORDS}

Climate Prosperity - A commitment to the creation of a low-carbon and prosperous American economy with focus on important regional economic outcomes, such as green savings, green opportunity, and green talent. Climate prosperity provides cities and regions with the opportunity to increase local economic growth, employment creation and development initiatives within the context of sustainable development.

Greenprint - A smart-growth strategy that emphasizes land conservation to ensure quality of life, clean air and water, recreation, and economic health (National Association of Counties and Trust for Public Land, 2010).

Green Economy - An economic development model that encourages the growth of clean and green industries to reduce greenhouse gas emissions. The reconfiguration of business infrastructure delivers better returns on natural, human and economic capital investments, while at the same time reducing greenhouse gas emissions, extracting and using fewer natural resources, creating less waste and reducing social disparities (The United Nations Environment Program, 2010).

Southwest Florida - The six counties in Southwest Florida that support energy efficiency improvements are Collier, Lee, Henry, Glades, Sarasota, and Charlotte. These counties have existing commitments from both government and business on waste reduction programs, clean, convenient transportation, water conservation and irrigation system programs, and energy initiatives.

Southwest Florida Climate Prosperity Council - A group of people that will lead the climate prosperity initiative in Southwest Florida. The members of the Council will represent business, government, academia, labor, and community organizations. 
NOTES 